\title{
EFFECTS OF THE IMPACT OF THE ACTIVE POLICIES ON THE LABOR MARKET
}

\begin{abstract}
Venelin Terziev
Academician of the Russian Academy of Natural History, Moscow, Russia, Prof. D.Sc. (Ec.), D.Sc. (National Security), D.Sc. (Social Activities), Ph.D., National Military University, Veliko Tarnovo, Bulgaria; University of Rousse, Rousse, Bulgaria, terziev@skmat.com

Abstract

The labor market is of crucial importance for the stability of enterprises, for economic and social development of the country, for the standard and quality of life. The labor market as one of the main markets that has an important role for the sustainable economic and social development of each country and region, the standard and quality of life of the population. Its development and situation have a direct influence on the development of the organizations and population. As one of the main markets, its development and status are determined by that of others, but the labor market itself has an impact on them in one way or another. The normal functioning of the economy, its dynamics, structure and efficiency determine the labor demand in volume, but also in structure, as well as the possible cost of labor. In a market economy, the organizations and enterprises find and provide themselves with resources, including also human resources, through the markets and in accordance with the rules, norms, institutions and the strategies and policies applied by them. The population, its income, professional and career development are carried out depending on the mechanisms, regulating the labor market and the management of economic activity and social life.
\end{abstract}

Keywords: labor market, active policies, effects, system, institutional structure.

\section{INTRODUCTION}

The labor market (along with the land market and the capital market) is one of the markets of factors of production. It is a specific mechanism for rational and efficient distribution and use of labor force for employment regulation. Economists use the term „labor market” as an analytical instrument in the search for answers to the questions- how is income allocated between individuals and households? Who does determine the amount of payment for the work performed?

The labor market is of crucial importance for the stability of enterprises, for economic and social development of the country, for the standard and quality of life. The labor market as one of the main markets that has an important role for the sustainable economic and social development of each country and region, the standard and quality of life of the population. Its development and situation have a direct influence on the development of the organizations and population. As one of the main markets, its development and status are determined by that of others, but the labor market itself has an impact on them in one way or another. The normal functioning of the economy, its dynamics, structure and efficiency determine the labor demand in 
volume, but also in structure, as well as the possible cost of labor. In a market economy, the organizations and enterprises find and provide themselves with resources, including also human resources, through the markets and in accordance with the rules, norms, institutions and the strategies and policies applied by them. The population, its income, professional and career development are carried out depending on the mechanisms, regulating the labor market and the management of economic activity and social life.

The labor market is often defined as a set of legal norms, principles, rules, requirements, procedures, institutions and policies that assist organizations to find the necessary labor force, and the active able-bodied population to find the desired job (position). It is the abstract place, where a market of the production factor "labor" is carried out, where "the transaction between buyers and sellers of labor" is carried out. It exists, when there is real demand and supply of labor and the cost of labor is determined by the ratio between them. It is a sort of mechanism for distribution of the labor force or the current economically active population, regulator of its motion, determines the level of employment and unemployment and determines the cost of different types of work (Georgiev, 2016; Georgiev, 2017-a; Terziev, Kanev, 2019; Terziev, 2019ak).

\section{MAIN CHARACTERISTICS AND FLOWS ON THE LABOR MARKET}

The labor market is a dynamic system in which the supply and demand for labor, hired people and employers interact. Main components of the labor market are the supply and demand for labor force, for labor; labor, labor force; labor cost; competition between demand and supply of labor. The subjects of the labor market are the employers and their representatives; the workers and employees and their representatives (professional and/or trade unions); the state and its authorities (the Ministry of Labor and Social Policy and its bodies- agencies, directorates, etc. directly related to the labor market). The institutions of the labor market are organizations, units or individuals, which connect in one form or another those, who seek labor force (the employers) and those, who offer labor force. Labor force (the economically active population) are the persons at the age of 15 or older, who put in or offer their labor to produce goods and services. Its scope includes both the employed and unemployed persons. They are the main actors in the labor market and determine the size and structure of the labor supply.

There are different definitions of the terms „employed” and „unemployed”. Some of them are commonly accepted within the International Labor Organization; others are used in the study of the labor market and population censuses, third are adopted in the system of public employment services. The accepted definitions determine the size and structure of the total employed, unemployed and economically inactive persons. According to one of the definitions, employed are the persons (at the age of 15 or older), who work under an employment contract, are hired to do a certain job for remuneration or work independently in order to receive income in cash or kind.

There are various definitions of the labor market in the economic literature. The diversity of definitions is a result of the different perspectives the labor market is considered from. They are as follows:

- In terms of the spatial aspect: the labor market is the place, where buyers and sellers of labor meet and carry out the purchase - sale of "labor" (the hiring of labor force);

- From an economic perspective: the labor market is the economic space, where the persons seeking and offering job can meet and negotiate;

- From an institutional perspective: the labor market is a system of legal norms, principles, institutions and organizations that define and regulate the relationship between the persons seeking and offering job.

As an economic category, the labor market marks the combination of all economic relations that arise and take place in the interaction between hired employees and employers. The labor market is a place for meeting able-bodied persons in need of paid work and resource owners looking to hire labor force. Here they can conclude a sort of „a deal” between buyers and sellers of labor force, strengthened with the conclusion of an employment contract that regulates the working conditions, remuneration, working hours, holidays etc.

The labor market is a special way to make contact between buyers and sellers of labor force.

The formation of the labor market requires the presence of:

- Physical persons, who are willing to replace part of their free time for paid employment;

- Physical or legal persons, who are looking to recruit labor force with relevant professional training and qualifications for a particular job;

- Institutional structure to mediate and regulate the relationship and interaction between persons seeking and offering labor force; 
- A specific infrastructure that helps the employees and employers to implement their goals and interests.

The essential characteristic of the labor market is related to the interaction between the supply and demand for labor.

The labor supply is the expressed will and ability of the able-bodied person to be hired at a certain level of remuneration and for a specified time. The aggregate labor supply is the sum of the individual supply and is determined by the number of able-bodied persons, the state of the economy, the labor productivity and work motivation.

The labor demand is the expressed will and opportunity of the employer to hire a certain number of employees, who have, in accordance with the requirements of the company, the necessary education and professional training. As in the demand for any other product, here we should also bear in mind that it is a question of solvent demand in terms of labor. This means that the employer assumes the responsibility and is able to pay an appropriate remuneration to the hired employees. The aggregate labor demand is the sum of the individual demand of all employers in the relevant labor market (Terziev, Kanev, 2019; Terziev, 2019ak; Terziev, 2018-d).

\section{INSTITUTIONAL STRUCTURE OF THE LABOR MARKET}

The institutional structure of the labor market includes the state institutions, non-governmental organizations of employees (represented by trade unions) and employers' organizations (such as the Bulgarian Chamber of Commerce and Industry, Bulgarian Chamber of Commerce); legislation (law framework of the labor market), collective agreements and other non-governmental organizations. The connection between those who supply labor and those who demand labor is made on the so-called labor exchanges. They contribute to the proper functioning of the labor market and the implementation of the national and regional employment policy. The labor exchange is an intermediary unit, which facilitates labor transactions between employees and employers. It:

- Provides the connection between employers and employees;

- Accelerates the implementation of the transactions on the labor market through better infor-mation, guidance and advice to its participants;

- Provides information services to employers and employees in the supply and demand for work;

- Collects and analyzes information on the situation on the labor market - state, trends;

- Analyzes information on problems related to the relationship of supply and demand for labor, the expansion of employment with the inclusion of socially vulnerable groups;

- Creates conditions for the optimization of employment;

- Develops and implements special programs for retraining and improving the qualification of the employees;

- Assists enterprises and organizations to create new job positions, etc.

The labor market also has certain social functions, expressed in the implementation of the national policy on employment and unemployment. It mixes the three main types of economic interests- those of the state, the employers and the employees, i.e. it works on the principle of tripartism. It has all those characteristics typical also for the other exchanges (commodity, stock, currency), but at the same time has a number of distinguishing features. Its main differences stem from the specifics of the agreed "commodity", namely the labor service.

The labor market is a mechanism for distribution of labor, human resources, regulator of employment, of the balance between the supply and demand for labor. From this perspective, it is a factor with an extremely strong impact on human resources management, its functions and activities (remuneration, planning of needs, formation, training, etc.). On the labor market the price of the production factor "labor" is established, respectively the rate and the level of employment and unemployment. Therefore, the labor market is a key regulator of the cost of labor and employment, respectively unemployment, whose level is directly dependent on the economic potential, economic growth, GDP.

Among the macroeconomic policies and means, a special place is occupied by the so-called active programs and measures on the labor market. They are a subject of increasing interest and discus-sions not only because of the expectations for tangible effects, but also because of the relatively significant financial resources, necessary for their implementation. The problem of the efficient spending has become more 
serious in the current situation of limited social spending in the country.

Building capacity for conducting regular monitoring and evaluation of the efficiency of the active poli-cies is one of the priorities of the European employment strategy. In the practical evaluation of the active programs and measures, the researcher often faces a number of problems stemming from their multi-purpose and multi-aspect nature; the lack of a unified and approved evaluation methodology, measurement errors and lack of adequate statistical information, objective impossibility to track persons and determining of the „benefits" from participation in such programs. The conducted over a hundred studies of different active programs worldwide give ambiguous and often contradicting results in terms of their effectiveness. The results are strongly influenced by the specifics of the country and the period and method of implementation of the programs.

The active programs can be generally considered as an instrument to support the effective functioning of the labor market. They help to remove obstacles and problems for the operation of the market economy. The active programs have a multi-target impact on the labor market. Developed as a means of reducing unemployment, today the anticipated effects of their use are too broad. Despite the presence of various modifications and specific manifestations in the implementation of active policies on the labor market, education and training of the unemployed persons are amongst the most important issues.

The active programs are a means of increasing the competitiveness of the labor force, of mobilizing the labor resources and enhancing the economic activity of the population. In the absence of credit resources, the micro-credit schemes become a real and often the only possibility for the development of small and medium business in the country. The active policy also performs a very important socio-distribution function, especially in the presence of disadvantaged groups in the labor market. As to the last, the participation in the active programs is often the only chance for employment and prevention of falling into extreme poverty and social deprivation (isolation). Last but not least, the degree of trust and support of the socio-economic reforms implemented in the country depends on the proper definition of the objectives and the expected results of the active programs and measures and their appropriate public disclosure.

The starting point in the assessment of the active programs and measures is the clarification of the goals, tasks and expected results for the respective program.

Studies of various active programs in the labor market show ambiguities and often contradicting re-sults on their effectiveness. The results are strongly influenced by the specifics of the country, the period and method of implementation of the programs. The specified wide range of objectives of the active programs shows that in their efficiency assessment, all possible aspects of performance should be analyzed and all the effectsimproving the opportunities for employment, improving the level of payment, the social impact etc. - should be measured and compared. Secondly, it is important to analyze the benefits and costs, which makes it possible to give a clear answer to the question of how the spent funds are economically and socially justified.

In the world practice, four types of assessment of active policies are mainly applied:

- Current monitoring and control of the programs;

- Assessment of the net impact of the programs;

- Analysis of the costs and benefits;

- Assessment of the institutional and organizational capacity of the programs.

Full research means the implementation of the four above described assessments. In practice, this is extremely expensive and therefore the assessments of the net impact are mostly applied. Most governments carry out continuous monitoring and control on the implementation of the programs. Even in the world practice, there are few comparative analyzes of costs and benefits, although this type of assessments proves the economic efficiency of spending on employment programs.

The efficiency of each program is measured by the achievement of the set goals. A program is effi-cient, when at its implementation it covers a significant part of the target group.

Furthermore, of interest is the immediate impact of the active policies on employment and income levels. In order to calculate the net effect on employment, it is necessary to ascertain how many of the participants in the program have been able to find a job after participation in it and how many of them would fail to do that, if they were not included in it. The net effect on earnings is measured as a relative share of the participants in the program, who after its completion report higher incomes than those, received prior to enrollment in the program. Thus, the increase in income is explained by the inclusion in the program. For the final efficiency measurement, it is necessary to compare the received net effects on the employment and income levels with 
the direct and indirect costs of the program. It is also possible to assess non-monetary effects, often called social.

In order for an active program to be fully efficient, at a macro level it is required to subtract the side effects from the resulting net effect on employment. Thus, we can ascertain the pure net effect or the real significance of the program as a means to reduce unemployment and increase the number of new job positions. As side effects, we can define:

The effect of the deadweight: the results of participation in a program might be obtained without participation in it. For example, in the case where an unemployed person is employed under a subsidized employment program, but would receive the same job without the presence of this program (preference for employer) the effect of the dead weight is present.

Substitution effect: such effect occurs when an unemployed person is employed under a subsidized employment program and receives a job that would otherwise be given to another person, not includ-ed in the program. The net effect in this case is zero.

Effect of displacement: this side effect is observed in the production process when a company, benefiting from subsidized employment, displaces from the market other companies that do not have benefits under subsidized employment programs.

The importance of comparing costs with revenues and benefits of each program can be illustrated by the following example. If the program for training and retraining of unemployed persons and the inter-mediary services give the same quantitative contribution (net effect) for increase of employment, but the money spent on training and retraining are two times higher than those for intermediary services, the first program will be twice less cost-effective than the second one.

For the last ten years, under the conditions of stagnating demand for labor, the quality imbalance between demand and supply of labor, high and sustainable unemployment and significant levels of poverty, problems of labor integration of unemployed persons from risk groups, deepens mainly because their low competitiveness on the labor market and low flexibility in the changing economic environment. The concentration of unemployed people from certain risk groups in certain areas and communities creates additional prerequisites for the high level of unemployment, and as a consequence- the occurrence of social tension.

The social policy changes in terms of unemployment, employment and social assistance that occur in the pre-accession period and after the country's accession to the European Union's structures, determine the need of a complex examination of the circumstances, programs and measures to be applied for achieving the global goal (Terziev, 2019a-k; Terziev, Arabska, 2014; Terziev, 2015-b; Terziev, Arabska, 2016a).

\section{PROPOSALS FOR INTEGRATED USE OF THE FUNDS UNDER THE COMMON STRATEGIC FRAMEWORK (CSF)}

In order to use more effectively all available resources to support the measures under the „Human resources development" Operational program, it is necessary to provide a better coordination of the HRDOP with the other operational programs. Binding can be made for example with the Development of the competitiveness of the Bulgarian Economy OP (DCBEOP), Regional development (RDOP) and Environment OP (EOP), funded by the European Regional Development Fund and the Cohesion Fund. This would lead to a more efficient and effective investment in human resources development, as well as to a more-effective interventions. This trend should be strengthened in the current pro-gramming period, as well as should include the preparation of a complementary and integrated ap-proach to the period after 2013.

In the next programming period a connection may be sought in the transfer of potential, created by the HRDOP, especially the EA (Employment Agency), measures for training of employed persons under programs that invest in large infrastructure projects (OPRD, TOP), as complex measures and integrated schemes are planned, to cover education (general, vocational, university) and training on the one hand, and demand for skilled labor force for maintenance and management of the established large-scale infrastructure, on the other.

In the current period, a connection may be sought between the HRDOP and the DCBEOP - the com-bination of measures under the HRDOP for training of employed persons and those under the DCBEOP in terms of business (investment in technological innovation, innovation capacity, research, collaboration with universities, technological parks, clusters, quality systems, etc.), which aim at increasing competitiveness.

Complementarity and coordination should be ensured of the HRDOP with the Financial Instrument for the 
Environment (LIFE), in particular with the integrated projects related to the mitigation of climate change. By measures financed under the HRDOP, activities in this area may be complemented through target education, training and improvement of the labor force qualification in relation to risk prevention and management and adaptation to climate change.

Synergies should be created with the Program for social change and social innovation, which supports the geographical mobility and facilitates the access of entrepreneurs to micro-financing, in particular of those entrepreneurs and micro-enterprises which are furthest in the labor market. Coordination should be ensured with the 'Erasmus for all', in particular with the projects for mobility and cooperation, related to school education, vocational education and training and adult learning.

The integration of the marginalized communities requires coherent and multidimensional approaches that are supported by the different funds under the CSF, complementing the national resources and implemented in compliance with reforms of the social protection systems. This multi-dimensional integrated approach that combines actions from various funds under the CSF, is particularly relevant for the implementation of interventions, directed to the Romani community (or segments thereof), whose effective integration requires investments in employment, education, health, housing and social integration.

In deprived urban areas, the activities for material and economic recovery, supported by the European Regional Development Fund (ERDF) should be implemented together with the activities under the European Social Fund (ESF) aimed at promoting the social inclusion of marginalized groups. In rural areas, the assistance of the European Agricultural Fund for Rural Development (EAFRD) may also be used to encourage social inclusion, in particular through community-led local development (LEADER), which will continue to be a compulsory element of the programs for rural development.

The integrated approach and integrated territorial interventions should be planned in accordance with the territorial scope of the areas for targeted support under Art.5 para. 5 of the Regional development act (RDA), determined in the regional development strategies. For this purpose, the activities on the provision of the necessary data from the National Statistics Institute and the administrative statistics of the Employment agency should be coordinated as well.

The pilot testing of integrated measures already within the current planning period is strongly recommended. Possible field for pilot testing is the innovation field, targeted by the EU programs for support of inter-regional cooperation for the regions of knowledge under the FP7, funded by the Framework Program for Competitiveness and Innovation and the Enterprise Europe Network. The opportunities, provided by the various financial instruments and their consolidation should also be tested.

Because of the crucial role for the formulation and implementation of integrated territorial interventions of the Communities for local development, it is necessary to help build capacity for development of strategies for community-led local development. This support may also cover the actual preparation, management and implementation of local strategies and the implementation of measures aimed at supporting the activities, prepared and implemented under the local strategy in areas falling within the scope of the HRDOP in the field of employment, education, social inclusion and institutional capacity building (Terziev, Kanev, 2019; Terziev, 2019a-k; Terziev, 2018-d; Terziev, Georgiev, 2018e-f; Terziev, Arabska, 2014; Terziev, 2015-b; Terziev, Arabska, 2016a).

\section{PROPOSALS IN THE FIELD OF SOCIAL CAPITAL, PARTNERSHIPS AND NETWORKS FOR SO-CIAL ECONOMY DEVELOPMENT}

\section{Support for social innovation}

Social innovation is an important new area, which is supported at EU level and can find a place in grant funding within the future programming period. At European level, the problems related to aging of the population, disability and inequalities, are encouraged and supported in terms of innovative approaches.

Currently in Bulgaria, there is potential for best practices for social innovation to be distinguished. Six social innovations, applied in Bulgaria (of a total of 226 at European level) are described on the website of the initiative for social innovations of the EC http://www.socialinnovationeurope.eu. Three of the described social innovations have the potential for multiplication and can be used as a basis for design of measures under the HRDOP:

- Social innovation in the field of education aimed at building the educational platform Ucha.se;

- The program of Solvay Sodi Innovation in action, presenting ideas for social innovation, which are available in popular social networks and sites; 
- Social innovation for transformation of skills of young people in the field of ICT (information and communication technologies) in job positions, funded by a foundation.

Social innovations, including the development and implementation of new ideas (products, services and models) require the establishment of new social relations or cooperation between the various organizations and stakeholders. The field of building networks and cooperation, as well as spreading of good practices have great potential for design of measures funded under the HRDOP in the field of social innovations.

Along with meeting the social needs, social innovations would provide an opportunity for establishment of new social relationships and models of collaboration, as well as for integration of existing regulatory systems. Thus, they will prove to be innovative in themselves and will help building an environment that supports and strengthens the ability of society to introduce innovations.

Suitable platform for the design of measures under the HRDOP, aimed at supporting social innova-tions, is a complementary financing of the measures under the National Action Plan to the Strategy for innovation and good governance at local level, prepared in cooperation with the Ministry of Regional Development and Public Works Works (MRDPW) and the National Association of Municipalities in the Republic of Bulgaria (NAMRB).

The design and implementation of social innovations, however, is a long process and requires a very close collaboration with stakeholders and implementation of a bottom-up approach in the programming processes and the assessment of needs. In addition, innovations, including social innovations, do not have an established base in Bulgaria and are not supported by ideas and initiatives at local level.

In this sense, piloting of measures, aimed at initiating and supporting social innovations already in the current planning period until 2013 is highly recommended. Pilot projects may have limited territorial scope, which would subsequently serve as a basis for integrated territorial interventions. Following the successful completion of the pilot projects (determined by a thorough assessment with involvement)

\section{Personalized support for measures that encourage employment of vulnerable groups}

At present, the activities on encouragement of employment of vulnerable groups suggest support to organizations / institutions. It is necessary to work for the development of measures to provide per-sonalized support, i. e. support directed to the individual and in compliance with their individual needs. This will contribute to achieving the priorities of the HRDOP in the field of social services and employment, related to the implementation of individual approach and the provision of individualized services. Examples of such an approach in the field of disabilities is the provision of a "service package” to the disabled people themselves, including for example provision of support at the workplace, covering transport costs, etc.

For the development of integrated services and ensuring the sustainability and efficiency of the ser-vices, we offer measures to be implemented, which will enable people with disabilities to receive the necessary support within the existing "Labor office" directorates, instead of investing in construction of individual support centers for people with disabilities. Thus, the construction of parallel services will be avoided and investments will be made in ensuring access to public services for disabled people, which is one of the main commitments under the Convention on the Rights of Persons with Disabilities, ratified by Bulgaria in 2012. The measures in this direction may also include development of the capacity of staff to work with and support disabled people.

The measures on active inclusion should support approaches to integration that combine various forms and measures to enhance employability, such as individual assistance, professional guidance, consulting, access to general and vocational education and training, as well as access to services, in particular health and social services, child care and Internet services.

It is necessary to work towards developing a network of support services for people with mental health problems, which in practice could not benefit from the services provided during the period 2007-2010. There are no services that provide support to people taking care of their relatives and friends.

Deinstitutionalization of elderly and disabled people, including people with mental health problems

The implemented measures under the HRDOP for deinstitutionalization are directed primarily to chil-dren. It is necessary for them to be extended, starting with the process of deinstitutionalization of elderly and disabled people with disabilities, including people with mental health problems.

In at the start of 2012 Bulgaria ratifies the Convention on the Rights of Persons with Disabilities, thus undertaking to adopt effective measures for social inclusion and participation in the community of people with disabilities including through the provision of: 
- Opportunity for disabled people to choose where and with whom to live, as they are not obliged to live under specific conditions;

- Access to a wide range of social services;

- Equal access to all public services and public facilities in a manner, appropriate to their needs.

In order for the results achieved to be sustainable, a clear vision and plan of action, binding the measures under the HRDOP with the implementation of the plan, implementation of the necessary legislative changes to support the implementation of the measures, as well as a long-term commitment by the state for financial and political support if the reforms, are required.

The work on deinstitutionalization should include two components - development of measures and services for deinstitutionalization, and measures and services for the prevention of institutionalization (for children this also includes a set of measures aimed at preventing abandonment). The planning of preventive measures should be based on a detailed analysis of the reasons for children abandonment, as well as the reasons for admission of children and adults to institutions.

Due to their complexity, the measures for deinstitutionalization can be supported by various financial instruments and co-financed by various operational programs through integrated interventions. Strengthening of the territorial focus of the measures and the design of integrated territorial interven-tions should also be considered - both in terms of specifying the needs of the target groups and in terms of the specifics of the regions for planning (Terziev, 2015-b).

\section{PROPOSALS IN THE FIELD OF LABOR MARKET AND HEALTH STATUS OF THE LABOR FORCE}

Support for entrepreneurship

Building entrepreneurial skills and knowledge among the economically inactive unemployed, combined with creating conditions and opportunities for starting private business, may counteract the tendency of reducing the number of self-employed persons. Interventions should be targeted to supporting entrepreneurship, selfemployment and launching a business (within the thematic objective of employment) and actions supporting social enterprises. Support for self-employment, targeted to unemployed, disadvantaged and inactive people (with a focus on skills development) should be supplemented to achieve integrity with measures funded under the DCBEOP and aimed at providing investment aid (co financed by the ERDF within the thematic objective of social inclusion).

\section{Encouraging the competitiveness of the small and medium enterprises (SMEs)}

Interventions should encourage the competitiveness of the SMEs, for example by developing the capacity of the SMEs to predict and manage changes, by providing support for organizational development and provision of information and consultancy services to the SMEs, by introducing innovative forms of work organization and/or flexible working time, as well as by encouraging enterprises to invest in training.

In connection with the need to enhance the competitiveness of the SMEs by supporting new enter-prises and activities in low-carbon and climate-change sectors, the need to strengthen the research, technological development and innovation in energy efficiency and renewable energy fields, and to boost employment and mobility of the labor force, measures should be planned to support the early ascertainment of needs and a shortage of labor force and specific skills and/or competences to reform education and training systems, adaptation of skills and qualifications, improving qualifications of the labor force in order to increase employability and support for creating new jobs in the sustainable low carbon industry and energetics.

\section{Measures for persons over working age}

It is appropriate to discuss the design of measures in the field of increasing labor supply and quality of labor force, which to attract people over working age to stay on the labor market, similar to those existing in many EU member states. This will reduce the pressure on the pension system, will extend the period in which skilled employees create surplus value, will create opportunities to pass on the gained experience to young people, who are just starting their career through mentoring program.

Particular priority should be given to ensuring conditions and support to keep the activity of elderly people and encourage healthy aging through measures aimed at supporting innovative forms of work organization that are favorable to elderly people, including accessible working environment and flexi-ble measures; extending working life in better health by developing and implementing measures to encourage healthy lifestyle and tackle health risk factors, such as sedentary lifestyle, smoking, harmful habits such as alcohol; 
encouraging employability and participation of older employees in schemes for lifelong learning, so that the active lifestyle of elderly people to be facilitated.

\section{Expanding the fields and forms of use of ICT}

In order to expand the fields and forms of use of ICT and actively contribute to enhancing digital literacy, the interventions should be aimed at encouraging digital competence in the systems of formal education and training, as well as ensuring effective training and certification on ICT outside the formal education systems, including the use of online instruments and digital resources for retraining and continuing professional development.

Special attention should be paid to increasing the attractiveness of the ICT sector for young people and social disadvantaged groups, including by e-services and other support measures (e.g. skills to use electronic equipment and easier access to services for e-learning, e-education, e-management, ehealthcare), as well as by provision of access to electronic technology for persons with special needs.

\section{Measures to encourage youth employment}

The recommended by the European Commission Services introduction of "Youth Guarantee" can be implemented by creating schemes that suggest measures for further education, training (retraining) or activation for all young people, who do not participate in any form of employment, education or training within a few months after leaving school. Special attention should be paid to vocational training, such as apprenticeships and internships for university graduates, in order to acquire initial professional experience. The introduction of the "Youth Guarantee” requires close cooperation with social partners, employment services, other stakeholders in the labor market and institutions for education and training. In particular, of crucial importance is the cooperation with employers, who provide training opportunities for young people at the workplace. For the new programming period, it is recommended that vocational training and job placement shall remain of priority. The existing scheme is very appropriate for young people, graduated from high school and for those who have a profession - it makes them much more competitive on the labor market. If they are not educated and/or do not have a profession - training in key competencies is not enough to ensure employment. Labor force adaptability

For a better adaptation of employees, enterprises and entrepreneurs to changes, the implementation of measures is recommended, aimed at the development of specific services for employment, training and support, including consultations, retraining and redirecting under the conditions of restructuring of companies and sectors; designing and implementing innovative, more productive and greener ways of work organization, including health and safety working conditions.

It is recommended that increasing of the level of qualification as continuing education under the voucher scheme is authorized, especially for people trained in more specific professions (e.g. plumb-ers). This requires a legislative change (Decree of the Council of Ministers №251), but the effect of the implementation of the scheme will be stronger (Terziev, 2015-b).

\section{INCREASED INVESTMENT IN HUMAN CAPITAL THROUGH A BETTER AND MORE ACCESSIBLE EDUCATION. CONCLUSION}

Implementation of innovations in the qualification and training of teachers

The emphasis should be laid upon implementation of innovations in the qualification and training of teachers, which focuses on practical application of knowledge of teachers and skills development for motivation and commitment of every student, cooperation with parents and visionary goal setting and planning of the learning process (Terziev, 2015-b).

Along with the measures for improving qualifications of teachers and lecturers, a system of evaluation and appraisal should be developed, to be connected with the qualification system. It can be developed as a national policy and set out in the relevant strategic documents.

Serious gaps exist in the field of evaluation and self-evaluation at schools, where the support of the system is still weak, as well as in the evaluation of the entire system. Increasing the management skills of directors, as well as improving the quality of school inspections have an indisputable effect on improving the organization of activities at schools and the quality and efficiency of the learning process.

Development of consulting and support for career development in the education system is a sphere that should be covered by the interventions under the program. In addition to vocational guidance, consulting and support for students should also be developed. This is a necessary measure, as it may include both students at risk of leaving school, and all the others, through consulting on their choice of form and sphere in which 
they will continue their education or training, including their orientation to a more rational choice.

Emphasis should be laid upon increasing the attractiveness of research and development activities, as well as improvement of working and development conditions of personnel in universities, research institutes and other institutions involved in such activities. Focused activities should ensure that persons, who meet the preliminary conditions for work in the field of research, are sufficiently motivated, would not abandon their research activities for a better-paid or prestigious social activity and have been provided with all necessary and appropriate conditions for the implementation of research and development activities. At the same time, the concentration of capacities and conditions for research and development activities should be increased in areas outside the capital. The provision of grants for research activities should be intensified.

Actuality of the HRDOP in a changed socio-economic and regulatory environment

Analysis and evaluation of the degree of actuality of the HRDOP under the conditions of a changed socioeconomic environment and compliance of the implemented measures with the changes in the socioeconomic situation and the identified needs

The comprehensive analysis of the actuality leads to the conclusion that the program is an important financial instrument to influence the employment field and will remain such in the next programming period as well. There is a specific scope and types of activities that complement the national policies, do not overlap with the EU programs and cannot be implemented in their entirety with other financial instruments. The measures are relevant, although they are implemented in a different socio-economic situation, compared to the situation in which the program document has been prepared.

\section{Compliance of the measures and interventions under the HRDOP with the national policies}

As a general conclusion, the evaluation confirms the correlation between the measures and the interventions under the HRDOP and the national policies, as these measures complement the national policies. The evaluation team assessed as a weakness of the external compliance of the HRDOP with the national policies the lack of strategic coherence with the strategic and planning documents for spatial planning and regional development- regional strategies and municipal development plans. The recommendations in this regard include:

Strengthening the territorial focus of the HRDOP, which should address key issues and meet the specific needs of the regions, while binding itself with the documents of strategic planning and spatial planning at a national and regional level. The same applies to the priorities of the strategies of the different territorial levels, which should be bound with the strategic documents of structural instruments and specifically with the HRDOP. The two processes should run in parallel, as they are interrelated.

The integrated approach and integrated territorial interventions should be planned in accordance with the territorial scope of the areas for targeted support under Art. 5 para. 5 of the Regional development act (RDA), determined in the regional development strategies. For this purpose, the activities on the provision of the necessary data from the National Statistics Institute and the administrative statistics of the Employment Agency should be coordinated as well.

Impact of the dynamics of changes in the European and national legal framework on achieving the strategic objectives of the HRDOP

Changes in legislation at national level shall follow all the legislative changes at EU level. In addition, in terms of structural funds, the national legislation, in an effort to respond to the current needs and due to the logical errors of every new legislative decision, seeking the best form of manifestation, is frequently changing. It can be summarized however, that the changes lead to its improvement and have a positive effect:

- The adopted measures by the Methodology for implementing financial corrections, directed to a better financial discipline in the spending of EU funds, allow the refunds to be returned to the budget of the operational program, and re-used as intended.

- The implementation of shorter deadlines for payment of grants after verification of expenditure by the respective Management authority / Intermediate unit is a necessary measure to reduce the effects of the financial and economic crisis on the timely implementation of the financed projects by increasing the working capital of the beneficiaries.

The procedures for granting financial assistance under the operational programs, co-financed by the Structural Funds and the Cohesion Fund of the European Union are optimized, the administrative burden in their implementation is reduced, a greater predictability is available by publishing the indicative annual work 
programs at an earlier stage, the preliminary publication of guidelines for application allows the removal of any omissions or inaccuracies/discrepancies in the procedure, etc.

A unified approach is implemented in determining a contractor by beneficiaries of agreed grant by the structural funds of the European Union, which are not contracting authorities under the Public procurement act, as the procedures are optimized, the administrative burden is reduced, more transparency and accountability are provided.

Impact of the changes in the functions of the administrative structures and units in the sphere of labor market, healthcare, education and social inclusion on the HRDOP interventions, aimed at institutional capacity and improvement of service provision

Based on the analysis of the legal and functional changes in the administrative structures and units in the spheres of labor market, healthcare, education and social inclusion, the following conclusions can be drawn for the period of evaluation:

There are no significant changes in the administrative system, i.e. no administrative structures have been closed and no new administrative structures have been opened. It is only the Social investment fund that has been closed, and the five Bulgarian-German vocational training centers have been transformed into a stateowned company, which continues to provide the same services. Therefore, maintaining the stability of the administrative system has not allowed a negative impact, but has facilitated the interventions under the program.

In most of the structures, internal restructuring has been made, in order to strengthen the capacity of the busiest departments and overcome the uneven workload of employees, which has improved the activity;

Branches with low standard of service have been closed, but this has not led to hampering or depriving the consumers of the service provided, as a new form of efficient service of users (by mobile teams) has been found;

There are actions that directly support the implementation of the interventions under the HRDOP:

- In the "General labor Inspectorate" Executive Agency (GLI EA) a new directorate has been opened„Administrative and information services and technologies”- for the development of the overall policy in the field of information technology, implementation of new information and communication technologies in the structures of the Agency, improving the services to individuals and legal entities by the Agency through the channels for access to services, including the provision of administrative services, etc.;

- New functions of the Agency for social assistance (ASA) have been regulated, in its capacity as an intermediate body of the HRDOP, related to the management, implementation and control of the measures under Priority Axis 5- „Social inclusion and promotion of social economy”;

- The General Directorate "Social Assistance” of the ASA have been assigned functions for the organization and conducting of trainings and consultations of unemployed persons for their inclusion in employment, related to the implementation of care for children from one to three years, within financed projects under the HRDOP, which are implemented by the Agency and/or other structures of the state administration;

- The „European Funds and International Projects” Directorate at the Employment agency has been restructured into General Directorate „European Funds and International Projects” with territorial units in all regional centers, as the number of employees has been increased to reach 100 people. By the establishment of the territorial units, the access to services provided by the directorate has been improved, and by increasing the number of the employees, its capacity has been strengthened.

- In the Employment agency, the access to the labor market has been improved. This has been done by switching to servicing of registered unemployed persons by mobile teams of officers of the Labor office directorate, based on the principle of an external workplace, which in turn contributes to the implementation of the measure "Spread and implementation of best practices in the management and operation of existing market institutions on the labor market;

- In the State Agency for Child Protection (SACP) a new directorate has been created- „Child state policy", which focuses on the capacity for policy development;

- The Regional Inspectorate of Education (RIE) has been assigned functions for organization and responsibility for the activities on implementation of state policy, related to the qualifications of pedagogical staff on the territory of the respective region; the departments "Inspection and organizational and methodical 
activities" at the RIE have been assigned functions on planning and support related to the organization on training of teachers, in order to improve their qualifications and career development; summarizing the qualification needs of the pedagogical staff in the field and contributing to the organization and conduction of various forms of qualifications of teachers at regional level;

- The identified changes in the functions of the administrative units are not significant, which has not impacted negatively on the interventions of the HRDOP in these key areas. In the restructuring, the employees have been reappointed in the new administrative units, which has preserved the administrative capacity.

An optimization has been made in all administrative structures, as the number of employees has been reduced.

In its entirety, the regulatory and functional changes in the administrative structures and units in the sphere of labor market, healthcare, education and social inclusion, made during the evaluation period, have a positive impact and support the implementation of the interventions under the HRDOP, aimed at institutional capacity and improvement of service provision.

Assessment of the implementation of the measures under the HRDOP aimed at improving labor supply and quality of labor force

The results of the conducted study with beneficiaries provide data for evaluation of significant indicators (achieving of goals, results, benefits from participation), attitudes (for future participation) and expectations of the respondents based on their specific program participation experience.

The assessment of the implementation of the program is positive in terms of results achieved, benefits for the organization and individuals from target groups, and the effect of participation for the development of business and staff. The main contribution as a result of participation is the achieved investment in the staff and organization development. The unplanned effects are indicative of a wide range of impact of the program. The results of the study confirm that the HRDOP is the main financial mechanism and the decisive factor that supports (Terziev, Arabska, 2014):

- Enterprises and organizations to improve the quality of products and services, labor productivity, improve working conditions and teamwork;

- Improvement of the quality of labor force in terms of its professional capacity and subjective profile, contributing to improving the self-esteem and motivation for work, development and career development;

- Improvement of the project culture and the capacity of beneficiaries to implement projects financed by the ESF.

Contribution of the HRDOP interventions to integration of vulnerable groups in the labor market. Support of the development of entrepreneurship

As a result of the review made on the progress of the indicators on the main activities for the integration of vulnerable groups and activation of persons outside the labor force, we can conclude that during the period 2007- 2010 the reported progress in implementing the target values of the indicators is not high.

As an initial stage for the implementation of operations for the integration of vulnerable groups in the labor market and attracting the inactive persons (and generally for the implementation of the HRDOP), the period covered by this assessment is characterized by carrying out preparatory work, gaining experience and current changes, restructuring of operations in response to changes in the socio-economic environment. The changes are determined by the need that interventions should respond adequately to the set priorities and identified needs in a dynamic environment (Terziev, 2015-b; Terziev, Arabska, 2016a).

\section{REFERENCE LIST}

Georgiev, Marin. (2016). Obshtestvenoto i ikonomichesko razvitie v konteksta na sotsialnite politiki. // Spisanie za nauka „Novo znanie“. Visshe Uchilishte po Agrobiznes i Razvitie na Regionite, 5, 2016, N 4, str. 26-41, ISSN 2367-4598 (Online), (Print) ISSN 1314-5703 (Георгиев, Марин. Общественото и икономическо развитие в контекста на социалните политики. // Списание за наука „Ново знание“. Висше училище по агробизнес и развитие на регионите, 5, 2016, N 4, стр. 26-41, ISSN 2367-4598 (Online), (Print) ISSN 1314-5703. 
Georgiev, Marin. (2017). Sbalansirovannaya karta kak alyternativa malogo biznesa. // Innovatsionnie tehnologii v nauke novogo vrmeni, Sbornik statey Mezhdunarodnoy nauchno - prakticheskoy konferentsii 1 fevralya 2017 g., Ufa NITS AETERNA, Chasty 1, 2017, s. 43-49, ISBN 978-5-00109004-5, ISBN 978-5-00109-007-6 (Георгиев, Марин. Сбалансированная карта как альтернатива малого бизнеса. // Инновационніе технологии в науке нового врмени, Сборник статей Международной научно - практической конференции 1 февраля 2017 г., Уфра НИЦ АЭТЕРНА, Часть 1, 2017, с. 43-49, ISBN 978-5-00109-004-5, ISBN 978-5-00109-007-6).

Georgiev, Marin. (2017a). Impacts of active social programs on labor market. // Mezhdunarodnayy nauchnayy zhurnal «Innovatsionnaya nauka». NITS Aeterna, N 02-1, 2017, pp. 139-143, ISSN 24106070 (Georgiev, Marin. Impacts of active social programs on labor market. // Международный научный журнал «Инновационная наука». НИЦ Аэтерна, N 02-1, 2017, pp. 139-143, ISSN 24106070).

Terziev, V., Kanev, D. (2019). Modern developments in behavioral economics. // Smart Technologies and Innovations in Design for Control of Technological Processes and Objects: Economy and Production Proceeding of the International Science and Technology Conference „FarEastCon-2018” Volume 138, October 2-4, 2018, Vladivostok, Russian Federation, pp. 10-23, 2019, (Print) ISBN978-3-030-15576-6, (Online) ISBN978-3-030-15577-3.

Terziev, Venelin. (2019a). Provision of integrated employment and social assistance services in Bulgaria. // Smart Technologies and Innovations in Design for Control of Technological Processes and Objects: Economy and Production Proceeding of the International Science and Technology Conference „FarEastCon-2018” Volume 138, October 2-4, 2018, Vladivostok, Russian Federation, pp. 24-39, 2019, (Print) ISBN978-3-030-15576-6, (Online) ISBN978-3-030-15577-3.

Terziev, Venelin. (2019b). Problems of control in the social sphere. // INTCESS 2019- 6th International Conference on Education and Social Sciences, 4-6 February, 2019, Dubai, International Organization Center of Academic Research, Istanbul, Turkey, pp. 577-593, ISBN: 978-605-82433-5-4.

Terziev, Venelin. (2019c). The criterion "competence” in the economic sector. // INTCESS 2019- $6^{\text {th }}$ International Conference on Education and Social Sciences, 4-6 February, 2019, Dubai, International Organization Center of Academic Research, Istanbul, Turkey, pp. 1241-1247, ISBN: 978-605-824335-4.

Terziev, Venelin. (2019d). Social policy and labor market development in Bulgarian transition period. // INTCESS 2019- $6^{\text {th }}$ International Conference on Education and Social Sciences, 4-6 February, 2019, Dubai, International Organization Center of Academic Research, Istanbul, Turkey, pp. 703-714, ISBN: 978-605-82433-5-4.

Terziev, Venelin. (2019e). Theoretical basis of development of labor market and social policy in the republic of Bulgaria. // INTCESS 2019- ${ }^{\text {th }}$ International Conference on Education and Social Sciences, 4-6 February, 2019, Dubai, International Organization Center of Academic Research, Istanbul, Turkey, pp. 715-726, ISBN: 978-605-82433-5-4.

Terziev, Venelin. (2019f). The problem of social efficiency- Indicators for social efficiency. // INTCESS 20196th International Conference on Education and Social Sciences, 4-6 February, 2019, Dubai, International Organization Center of Academic Research, Istanbul, Turkey, pp. 669-678, ISBN: 978605-82433-5-4.

Terziev, Venelin. (2019g). Experiencing social policy development and efficiency measurment. // INTCESS 2019- 6th International Conference on Education and Social Sciences, 4-6 February, 2019, Dubai, International Organization Center of Academic Research, Istanbul, Turkey, pp. 679-686, ISBN: 978605-82433-5-4.

Terziev, Venelin. (2019h). Efficiency and assessment of social technology. // INTCESS 2019- $6^{\text {th }}$ International Conference on Education and Social Sciences, 4-6 February, 2019, Dubai, International Organization Center of Academic Research, Istanbul, Turkey, pp. 687-694, ISBN: 978-605-82433-5-4.

Terziev, Venelin. (2019i). Conceptual framework of social adaptation. // INTCESS 2019- $6^{\text {th }}$ International Conference on Education and Social Sciences, 4-6 February, 2019, Dubai, International Organization Center of Academic Research, Istanbul, Turkey, pp. 494-503, ISBN: 978-605-82433-5-4.

Terziev, Venelin. (2019j). The dependence social adaptation- socialization. // INTCESS 2019- $6^{\text {th }}$ International Conference on Education and Social Sciences, 4-6 February, 2019, Dubai, International Organization Center of Academic Research, Istanbul, Turkey, pp. 478-485, ISBN: 978-605-82433-5-4. 
Terziev, Venelin. (2019k). Social activity and human resources as social development factors. // INTCESS 2019- $6^{\text {th }}$ International Conference on Education and Social Sciences, 4-6 February, 2019, Dubai, International Organization Center of Academic Research, Istanbul, Turkey, pp. 546-553, ISBN: 978605-82433-5-4.

Terziev, Venelin. (2018). The active model of a social programme and its strategic advantage // ADVED 2018- $4^{\text {th }}$ International Conference on Advances in Education and Social Sciences Abstracts \& Proceedings, 15-17 October 2018- Istanbul, Turkey, International Organization Center of Academic Research, www.ocerints.org, Istanbul, Turkey, 2018, pp. 189-203, ISBN: 978-605-82433-4-7.

Terziev, Venelin. (2018a). Active social programs development in Bulgaria: contemporary challenges and social management instruments. // ADVED 2018- $4^{\text {th }}$ International Conference on Advances in Education and Social Sciences Abstracts \& Proceedings, 15-17 October 2018- Istanbul, Turkey, International Organization Center of Academic Research, www.ocerints.org, Istanbul, Turkey, 2018, pp. 149-163, ISBN: 978-605-82433-4-7.

Terziev, Venelin. (2018b). Social assistance services and integrated employment in Bulgaria. // ADVED 2018- $4^{\text {th }}$ International Conference on Advances in Education and Social Sciences Abstracts \& Proceedings, 15-17 October 2018- Istanbul, Turkey, International Organization Center of Academic Research, www.ocerints.org, Istanbul, Turkey, 2018, pp. 164-177, ISBN: 978-605-82433-4-7.

Terziev, Venelin. (2018c). Impact of the labor market policies for ensuring employment. // ADVED 2018- $4^{\text {th }}$ International Conference on Advances in Education and Social Sciences Abstracts \& Proceedings, 1517 October 2018- Istanbul, Turkey, International Organization Center of Academic Research, www.ocerints.org, Istanbul, Turkey, 2018, pp. 178-188, ISBN: 978-605-82433-4-7.

Terziev, Venelin. (2018d). Importance of human resources to social development. // ADVED 2018- 4th International Conference on Advances in Education and Social Sciences Abstracts \& Proceedings, 1517 October 2018- Istanbul, Turkey, International Organization Center of Academic Research, www.ocerints.org, Istanbul, Turkey, 2018, pp. 204-212, ISBN: 978-605-82433-4-7.

Terziev, V., Georgiev, M. (2018e). A strategic framework for the development of social entrepreneurship in Bulgaria. // Knowledge - International Journal, August 2018, Institute of Knowledge Management, Skopje, Macedonia, 25, 2018, N 1, pp. 23-34, ISSN 1857-923X (for e-version), ISSN 2545 - 4439 (for printed version).

Terziev, V., Georgiev, M. (2018f). Support for the development of social entrepreneurship in Bulgaria. // Knowledge - International Journal, September, 2018, Institute of Knowledge Management, Skopje, Macedonia, 26, 2018, N1, pp.57-74, ISSN 1857-923X (for e-version), ISSN 2545 - 4439 (for printed version).

Terziev, V., E., Arabska. (2014). Assessment of active social policies' impacts on labor market in the Republic of Bulgaria. Kolektivnaya monografiya "Sotsialyno-ekonomicheskie i pravovay razvitiya ekonomiki“, Ufa, Aeterna. Rossiya, 2014. ISBN 978-5-906769-97-8, str. 3-57 (Terziev, V., E. Arabska. (2014). Assessment of active social policies' impacts on labor market in the Republic of Bulgaria. Колективная монография „Социально-экономические и правовы развития экономики“, Уфа, Аэтерна. Россия, 2014. ISBN 978-5-906769-97-8, стр. 3-57).

Terziev, Venelin. (2015). Impact of active social policies and programs in the period of active economic transformations in Bulgaria, „East West” Association for Advanced Studies and Higher Education, Vienna, 2015, ISBN 78-3-903063-44-0, 434 p.

Terziev, Venelin. (2015a). Assessment of active social policies impact of social policies on transformation processes in bulgarian economy, Moscow, 2015, Publisher „Перо“, 110 p.

Terziev, Venelin. (2015b). Opportunities for improving the efficiency of the social adaptation of servicemen discharged from military service in Bulgaria:- Novosibirsk: Publisher CRNS, 2015. ISBN 978-5-00068402-3, 270 p.

Terziev, V., E., Arabska. (2016a). Effektivnoe vliyanie na raynok truda posredstvom uluchsheniya realizatsii sotsialynoy politiki. Novosibirsk: Izdatelystvo TSRNS, 2016. ISBN 978-5-00068-496-2, $312 \mathrm{str}$ (Терзиев, В., Е. Арабска. (2016а). Эфрфективное влияние на рынок труда посредством улучшения реализации социальной политики. Новосибирск: Издательство ЦРНС, 2016. ISBN 978-5-00068-496-2, 312 стр). 